\title{
УРАЛЬСКАЯ ШКОЛА
}

ПОЛИТИЧЕСКОЙ ДИСКУРСОЛОГИИ: НОВЕЙШИЕ ИССЛЕДОВАТЕЛЬСКИЕ НАПРАВЛЕНИЯ И АКАДЕМИЧЕСКИЕ ПРАКТИКИ

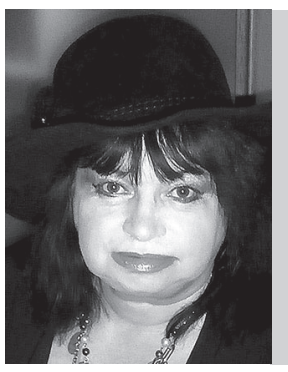

\author{
Русакова Ольга Фредовна, \\ Институт философии и права \\ Уральского отделения Российской академии наук, \\ доктор политических наук, профессор, \\ Екатеринбург, Россия, \\ E-mail: rusakova_mail@mail.ru
}

\section{Аннотация}

В статье рассматриваются новейшие направления разработки уральскими учеными, прежде всего в лице научных сотрудников и аспирантов Института философии и права УрО РАН, теоретико-методологической базы политической дискурсологии как новой отрасли современных политических исследований. Раскрывается содержание основных тематических блоков политической дискурсологии, получивших теоретическое развитие в коллективных трудах и монографиях уральских ученых, изданных в последние годы. Рассматриваются важнейшие итоги реализации конкретных исследовательских проектов в области политической дискурсологии, анализируется опыт организации научного обмена в формате конференций.

Ключевые понятия:

политическая дискурсология, политический дискурс, медиадискурс, дискурс мягкой силы, дискурс мобильности, дискурс политики памяти, дискурс Модерна, дискурс постфордизма, дискурс посткапитализма, дискурс неомарксизма, дискурс гражданственности, дискурс трансгуманизма, дискурс гуманитарных интервенций, дискурс академического письма, профессиональный дискурс.

Летоисчисление Уральской школы политической дискурсологии начинается с момента учреждения в 2001 году научного издания - Научно-практического Альманаха «Дискурс-Пи», который в 2013 г. получил новое название - Научный журнал «Дискурс-Пи» [11; 59; 67]. Инициаторами издания стала группа сотруд- 
ников Института философии и права УрО РАН, которые составили творческое ядро Уральской школы политической дискурсологии.

Первыми крупными работами школы стали две коллективные монографии: «Многообразие политического дискурса» [30] и «Современные теории дискурса: мультидисциплинарный анализ» [28; 69]. В них были обозначены предметнотематические контуры политической дискурсологии как новой научной дисциплины, представлены классификации зарубежных и отечественных теорий дискурса, предлагались авторские версии специфики разнообразных видов политического дискурса - демократического, дискурса гражданственности, дискурса справедливости, дискурса политического постмодерна, дискурса политической науки и др.

В самом начале деятельности научной школы ее ключевой методологической установкой в области дискурс-исследований, ее своеобразной визитной карточкой стало изучение политического дискурса с позиций коммуникативносемиотического и кратологического подходов. Иначе говоря, политический дискурс рассматривался в качестве коммуникативного актора, властного ресурса, инструмента интерпретации политической реальности, способа ее символизации и смыслонаполнения. В 2003-2005 гг. при поддержке гранта Президента Российской Федерации (грант № НШ-2228.2003.6) уральские дискурсологи проводили большую исследовательскую работу в рамках проекта «Методология дискурс-анализа в социально-политических и гуманитарных науках». Результаты исследований получили отражение в нескольких сериях журнальных публикаций, в том числе - в журналах «Полис: Политические исследования» $[29 ; 54 ; 70 ; 72]$ и «ПОЛИТЭКС: Политическая экспертиза» [46; 73].

В программной статье, опубликованной в № 4 журнала Полис за 2006 г., были систематизированы основные методологические подходы к изучению политического дискурса (критический дискурс-анализ, социосемиотический подход, социокультурный дискурс-анализ, постмодернистский подход и др.). Там же рассматривались основные структурные компоненты (планы) политического дискурса: интенциональный, актуальный, виртуальный, контекстуальный, психологический, осадочный. Там же были обозначены основные функции политического дискурса: (1) функция культурно-символической репрезентации власти; (2) функция смыслопорождения и идентификации; (3) функция коммуникативного и эмоционального доминирования [54].

Важными вехами в научно-организационной деятельности Уральской школы политической дискурсологии стали ежегодные научно-практические конференции «Дискурсология: Методология. Теория. Практика», которые в 20062008 гг. проводились в Екатеринбурге, а с 2009 года их постоянной локацией стал Южно-Уральский государственный университет (г. Челябинск). Непременными участниками данных конференций являются мексиканские коллеги, работающие в Национальном Автономном университете Мехико (UNAM, Мехико, Мексика) и в Автономном университете штата Мехико (UAEM, Толука, Мексика) [14; 15 ; $16 ; 39 ; 71]$.

В 2007 г. по инициативе Института философии и права УрО РАН была учреждена Международная академия дискурс-исследований (МАДИ), действительными членами которой стали многие известные российские и зарубежные дискурсологи, среди них: В.Г. Богомяков (г. Тюмень), М.В.Гаврилова (г. Санкт-Петербург), М.В. Ильин (г. Москва), Е.А. Кожемякин (г. Белгород), А.С. Кузнецов (ун-т. 
Альберта, Канада), Г. Саймонс (г. Упсала, Швеция), Ле Куи Куинь (г. Хошимин, Вьетнам), О.Ю. Малинова (г. Москва), М.А. Малышев (г. Мехико, Мексика), Л.В. Селезнева (г. Москва), Л.Н. Синельникова (г. Ялта, Крым), Л.Н. Тимофеева (г. Москва) и др. [6].

За последнее десятилетие представителями Уральской школы политической дискурсологии издано несколько монографий и коллективных работ, посвященных исследованию разнообразных дискурсов: дискурс современной политической философии [47], дискурс PR [55], политический медиадискурс [21], дискурс травелога [12; 13], дискурс мягкой силы [80], дискурс будущего [4], дискурс региональной идентичности [5], дискурс постфордизма [38].

Среди фундаментальных исследовательских проектов Уральской школы политической дискурсологии особое место занимает энциклопедический проект «Дискурсология». Данный проект получил поддержку РГНФ и других научных фондов, выделивших гранты научному коллективу: грант РФФИ-«Урал» 0703-83305 «Уральская школа политической дискурсологии: инновации и направления научных исследований». 2007-2008; грант РФФИ-«Урал» 09-03-83303 a/y «Содержательная модель научной энциклопедии «Дискурсология»: концептуальные основания, структурно-тематические блоки, тезаурус» 2009-2010; грант в рамках конкурсных программ фундаментальных научных исследований, выполняемых по программам тематических отделений РАН: проект № 12-И6-2066 «Создание сетевого ресурса «Теория и методология дискурс-анализа в современной науке». Методологической базой энциклопедического проекта является конгломерат исследовательских методов: метод классификации и типологии, методы персонологии, методы контент-анализа, контекст-анализа, дискурс-анализа.

Значительное внимание в энциклопедическом проекте предполагается уделить структурно-содержательному препарированию разнообразных видов политических, социокультурных и правовых дискурсов, а также - рассмотрению разнообразных методов дискурс-исследований и анализу концептов. Авторы проекта считают, что дискурсы как источники возникновения смысловых множеств образуют концептуальные поля. Концепт - это ментальное образование, которое осуществляет смысловую кристаллизацию дискурсов в форме подвижной когнитивной решетки (матрицы), лежащей в основе конструирования и видения реальности [47, с. 90-92]. К примеру, дискурс травелога кристаллизуется в смысловых полях таких концептов, как «путешествие», «паломничество», «странствие», «дорога», «маршрут», «карта», «гостеприимство» и др. Анализ концептов непременно сопровождается раскрытием содержащихся в них метафорических образов и мифологем, а также - ценностных, семиотических и коммуникативных аспектов. Появление новых содержательно близких концептов образует когнитивную систему, которая обозначается термином «концептосфера». К примеру, концептосферу политического медиадискурса образуют такие понятия, как «медиакратия», «медиатизация политики», «медиацентрированная демократия» и др. [51].

Тексты статей, предоставляемые организаторам данного проекта, регулярно публикуются на страницах Научного журнала «Дискурс-Пи» в специальной рубрике «Энциклопедия «Дискурсология». К настоящему времени опубликованы и готовятся к изданию 220 энциклопедических статей. В состав редколлегии 
энциклопедии входят известные руководители российских дискурсологических школ: М.В. Гаврилова (г. Санкт-Петербург), Т.В. Дубровская (г. Пенза), М.Р. Желтухина (г. Волгоград), В.И. Ильин (г. Москва), В.И. Карасик (г. Волгоград), Е.А. Кожемякин (г. Белгород), А.В. Полонский (г. Белгород), Т.Н. Митрохина (г. Саратов), А.В. Олянич (г. Волгоград), А.В. Полонский (г. Белгород), Л.Н. Синельникова (г. Ялта) и др.

Значительный вклад в формирование понятийной базы энциклопедического издания внесла доктор филологических наук, профессор Марина Владимировна Гаврилова [8], в серии статей которой дан глубокий лингво-политологический анализ различных жанров публичного политического дискурса. Существенную помощь в создании энциклопедических трудов, посвященных разнообразным видам дискурса, оказал доктор филологических наук, профессор Владимир Андреевич Олянич. Он совместно с коллегами - лингво-культурологами - представил для энциклопедического проекта большой массив статей, посвященных анализу тематически разнообразных дискурсов социокультурного плана. В их числе статьи, предметом рассмотрения которых выступают: автомобильный дискурс, вакхический дискурс, гастрономический дискурс [36], ихтио- и аквадискурс [37], сакральный дискурс [3], дискурс институциональной глюттонии [2], сказочный дискурс [1] и др.

Активными участниками проекта, написавшими целый ряд оригинальных статей для Энциклопедии «Дискурсология», стали сотрудники Института философии и права УрО РАН. Среди них - Ирина Борисовна Фан, опубликовавшая статьи, в которых анализируются разные виды дискурса гражданственности [73; 75; 76; 77], Кира Степановна Романова, посвятившая статьи рассмотрению дискурса имени, имиджа, анекдота [42], Екатерина Григорьевна Грибовод, сделавшая предметом своего анализа такие понятия, как «медиадискурс», «Интернетдискурс», «дискурс социально-политического проектирования» [9].

Уральским дискурсологам удалось установить долговременное научное сотрудничество с другими дискурсологическими сообществами России. Тесная научная кооперация сложилась между Уральской школой политической дискурсологии и Белгородской школой изучения дискурса современных масс-медиа, действующей на базе кафедры коммуникативистики, рекламы и связей с общественностью Белгородского национального исследовательского университета под руководством доктора философских наук Евгения Александровича Кожемякина. Сотрудничество осуществляется как в форме совместного участия в проведении научных конференций, так и в реализации энциклопедического проекта. Представителями Белгородской школы было предоставлено более 20 статей для энциклопедии «Дискурсология» [23; 24; 27].

Когда в 2016 г. на базе Ялтинского филиала Крымского федерального университета им. В.И. Вернадского был учрежден Ялтинский дискурсологический кружок (ЯДК) под руководством доктора филологических наук, профессора Лары Николаевны Синельниковой, уральские дискурсологи сразу же включились в его работу. Кроме того, одним из учредителей ЯДК стала Международная академия дискурс-исследований (МАДИ). Печатным органом ЯДК был официально объявлен Научный журнал «Дискурс-Пи» [66]. Статьи участников конференций ЯДК, в том числе статьи, предназначенные для Энциклопедии «Дискурсология», регулярно публикуются на страницах данного журнала [68]. 
Работа над энциклопедическим проектом осуществлялась также в рамках конкурсных программ фундаментальных научных исследований, выполняемых по программам тематических отделений РАН: проект № 12-И6-2066 «Создание сетевого ресурса «Теория и методология дискурс-анализа в современной науке». Проект выполнялся сотрудниками двух подразделений УрО РАН под руководством заведующей отделом философии Института философии и права УрО РАН Русаковой Ольги Фредовны и директора Научной библиотеки УрО РАН Полины Прокопьевны Тресковой. В итоге была создана электронная версия энциклопедии «Дискурсология». Руководители и участники проекта разработали концепцию электронного ресурса «Теория и методология дискурс-анализа в современной науке», провели методическую работу по созданию базы данных о ведущих научных школах дискурс-исследований, существующих в России и за рубежом. В процессе реализации данного проекта была предложена авторская методика отбора статей, необходимых для включения в электронный ресурс, создан тематический рубрикатор и словник энциклопедии для автоматизированной библиотечно-информационной системы ИРБИС, введен первичный массив данных отечественных и зарубежных работ по основным рубрикациям.

С 2014 г. одним из центральных исследовательских направлений Уральской школы политической дискурсологии стала разработка теории дискурса soft power (мягкой силы) [50; 56]. Данной теме были посвящены три научные конференции, которые состоялись в 2014, 2017 и 2018 гг. Значительная часть докладов конференций публиковалась в специальных рубриках нескольких номеров Научного журнала «Дискурс-Пи» [7; 34; 52; 64], а также была представлена в виде электронного издания [31]. В 2015 г. на основе материалов Первой конференции, посвященной дискурсу мягкой силы, была издана коллективная монография «Soft power: теория, ресурсы, дискурс» [80], которая была удостоена Премии второй степени Российской ассоциации политической науки (РАПН) в номинации монографических работ. В монографии комплексно проанализированы проблемы методологического анализа концепта мягкой силы, обобщен международный опыт формирования национальных моделей soft power, paсcмотрены различные рейтинговые системы, направленные на измерение тех или иных параметров мягкой силы государств.

В последнее время новыми областями углубленных научных исследований представителей Уральской школы политической дискурсологии стали дискурсы мобильности и дискурсы политики памяти. Изучению дискурса мобильности был посвящен специальный тематический номер Научного журнала «Дискурс-Пи» (2013. № 13). В нем рассматривались такие исследовательские направления, как метафорика и концептосфера дискурса мобильности [35; 48], формы мобильности в травелоге [40], концепт «человека движущегося» (скитающегося) [44], современные тренды студенческой мобильности [25], мобильность как фактор политической социализации [32], идеологическая мобильность неолиберализма [79] и др.

Пристальное внимание современных исследователей к дискурсу мобильности и связанный с этим быстро растущий объем научных работ в области mobility studies уральские дискурсологи объясняют универсальным характером феномена мобильности, который в эпоху информатизации и высоких скоростей 
оказался чуть ли не главным коммуникативным капиталом, ресурсом креативности и фактором инновационности.

Парадигма мобильности включает широкий спектр восприятия феноменов изменчивости, ускорения, текучести социальных форм и процессов. В настоящее время она глубоко и прочно встроена в практику исследований медийного пространства и образующих его медиадискурсов. Уральскими учеными выделяются и рассматриваются следующие тенденции в развитии медиареальности, сложившиеся под влиянием парадигмы мобильности: увеличение темпов роста объемов информации и одновременно информационного «шума»; возрастание скорости порождения информации на основе новой технической инфраструктуры; возрастание скорости формирования стандартов восприятия информации, способов ее кодирования-декодирования; замещение логико-рациональных компонентов медиадискурса визуально-эмоциональными и др. [63].

Исследования научной школы в сфере разработки концепта и теории дискурса мобильности получили поддержку в виде гранта, который был выделен Институту философии и права УрО РАН под проект фундаментальных исследований: проект № 15-19-6-1 «Разработка концепта мобильности в современных гуманитарных и социально-политических исследованиях: теоретикометодологический анализ». В соответствии с программой его реализации уральскими учеными был организован круглый стол «Философия, культура и дискурс мобильности», который был проведен во время работы VII Российского Философского Конгресса (Уфа, октябрь 2015 г.). Доклады и материалы круглого стола были опубликованы в отдельном номере Научного журнала «ДискурсПи» [57]. В центре внимания докладчиков - теоретико-методологические вопросы изучения дискурса мобильности, конкретные проблемы дискурс-анализа различных форм и видов мобильности $[10 ; 19 ; 23 ; 33 ; 41 ; 45 ; 74 ; 78]$. В процессе работы над изучением методологического потенциала парадигмы и дискурса мобильности был сделан вывод о том, что опираясь на теорию дискурса мобильности, можно прийти к обнаружению новых, порой неожиданных аспектов осмысления политических реалий. К примеру, можно выявить исламские измерения дискурса мобильности [20] или вскрыть ранее не обнаруженный исследователями историко-политический смысл большевизма [65].

Одним из инновационных достижений уральских дискурсологов является теоретико-методологическое «скрещивание» двух дискурсивных и парадигмальных систем - концепта мягкой силы и концепта мобильности. Данной проблематике была посвящена работа Всероссийской научно-практической молодежной конференции «Мобильность как измерение мягкой силы: теория, практика, дискурс» (Екатеринбург, 17 октября 2018). Синтез двух концептов мягкой силы и мобильности - означает, во-первых, придание особой значимости феномену стратегической гибкости, тактической подвижности в ходе реализации конкретных программ развития мягкой силы. Во-вторых, включение фактора мобильности в теоретико-методологический арсенал государственных практик мягкой силы. В-третьих, мобильность, рассматриваемая в качестве способности оперативно реагировать и отвечать на новые запросы общественного развития в государствах, выступающих объектами воздействия мягкой силы, становится важным показателем ее управленческих возможностей и глубины проникновения в социальную, экономическую и информационную ткань данного государ- 
ства. В-четвертых, мобильность мягкой силы предполагает умение оперативно соединять в одной стратегической программе разнообразные инструменты мягкой силы, способность вовремя их перегруппировать в соответствии с изменившимися обстоятельствами. В-пятых, мобильность мягкой силы - это ее способность развиваться и усиливаться в едином ансамбле с инструментами «жесткой силы», то есть выступать в качестве smart power (умной силы) [49; 63].

В целом, под мобильностью как значимой характеристикой мягкой силы понимается оперативность, своевременность ее практического применения, отзывчивость к новизне общественных запросов, комплексность использования разнообразных инструментов мягкого влияния. Особый интерес у исследователей вызывают такие виды мобильности, как Интернет-мобильность, коммуникативная мобильность, маркетинговая мобильность, миграционная мобильность, академическая, университетская, культурная мобильность и др. Многие виды мобильности рассматриваются в качестве атрибутивных характеристик определенных форм мягкой силы. К ним, в первую очередь, относится целый ряд рейтинговых показателей развития soft power отдельных стран: immigration (миграционная привлекательность), tourism (развитие туристической инфраструктуры и услуг для туристов), university ranking (университетский рейтинг), digital ranking (рейтинг развития цифровых технологий), engagement (успехи страны в области глобального сотрудничества, развитость и достижения публичной дипломатии) [49].

Изучение фактора мобильности как значимой характеристики мягкой силы страны сегодня особенно важно для России, которая стремится усилить свое влияние на постсоветском пространстве. Вместе с тем, до сих пор отсутствует четкий системный подход к научному проектированию отечественных стратегий по развитию мягкой силы с позиции усиления ее мобильных компонентов. Следует также отметить, что стратегия усиления мобильности для России, связанная с широким применением инструментов мягкой силы, пока еще не выработала концепции необходимого баланса между мягкими и жесткими способами влияния, что необходимо для реализации политики умной власти (smart power). Попытки же нынешнего руководства страны сформулировать данную стратегическую программу нередко приводят не к оживлению инновационных поисков, а к подъему консервативно-охранительных настроений.

Усиление информационного противостояния в мировой политике, в частности в сфере интерпретации прошлого, вызвало у дискурсологов большой интерес к проблематике исторической и национальной памяти. В этой связи был разработан исследовательский проект «Стратегические установки и технологии реализации политики национальной памяти на постсоветском пространстве в контексте информационной безопасности России» (проект фундаментальных исследований Института философии и права УрО РАН: № 18-6-6-8). Ранее участники данного проекта уже имели определенный научный задел в области изучения разнообразных технологий политики памяти и их дискурсивных проявлений. По данной теме было сделано несколько докладов на российских и международных конференциях, написаны разделы в сборниках трудов [26; $43 ; 58 ; 60 ; 61 ; 62]$.

В работах уральских ученых политика памяти рассматривается как продуманная система форм и способов политизации прошлого в целях управления 
коллективной исторической памятью народа. Подчеркивается, что в каждой стране существует собственная проблематика политики памяти, своя история сопротивления по отношению к данной политике. В новых государствах стран Восточной Европы политика памяти выполняет функцию переосмысления советского прошлого с позиции ответственности СССР и России как его преемницы за преступления тоталитарного режима. В последнее время широкое распространение получает так называемая «оккупационная риторика», связанная с выявлением все новых данных о преступлениях советского режима против человечества. Сегодня в политическом истеблишменте стран СНГ и Балтии негативную, взрывную реакцию вызывает все, что связано с памятью о Великой отечественной войне. Корни активизации негативного уклона в политике памяти на постсоветском пространстве следует искать в кризисе национальной идентичности, который возник в новых независимых государствах в результате распада СССР, а также - в стремлении властных кругов новых государств к радикальной переориентации общества на ценности потребительского образа жизни и неолиберального мироустройства.

Важным направлением изучения современных дискурсов политики памяти для уральских дискурсологов стал критический анализ официального государственного дискурса о советском прошлом. Особенно пристальное внимание уделяется исследованию неолиберального дискурса, направленного на переинтерпретацию истории Второй мировой войны. Как выяснилось, типичным для данного дискурса является ревизия позиции советской историографии относительно причин и характера Великой Отечественной войны. В последние десятилетия культивируется тезис о том, что Великая Отечественная война была такой же агрессией, как и гитлеровская, имела захватнический или даже колониальный характер, о чем, якобы, свидетельствует «освободительная борьба» украинских, прибалтийских, кавказских и иных националистов против советских оккупантов. Стал широко распространяться тезис о равной ответственности нацистской Германии и Советского Союза за развязывание Второй мировой войны, о сговоре Гитлера и Сталина по поводу раздела демократической Европы. В европейском дискурсе политики памяти сложился и утвердился постулат о том, что государства Восточной Европы были жертвами сразу двух оккупационных практик - гитлеровской и советской [61; 62].

Специальным предметом исследования для уральских ученых стал официальный российский дискурс политики памяти, связанный с оценкой современной властью переломных вех в истории советского государства. Отмечается невнятный идеологический характер данного дискурса, его неопределенность объясняется гибридной, по сути, системе ценностных ориентаций современной элиты страны. Эта особенность наиболее ярко проявила себя в периоды приближения крупных юбилейных дат - 100-летие Великой Октябрьской социалистической революции, 100-летие Красной Армии, 100-летие ВЛКСМ. В своих работах уральские ученые обращают внимание на логически противоречивый характер официальных трактовок смысла и значения памятной даты 7 ноября, дают подробное объяснение тому факту, что политическая элита России фактически отказалась от широкого празднования столетнего юбилея Великого Октября. Отсюда - характерное название данного дискурса - «тихий юбилей» [53]. 
Предметом отдельных дискурс-исследований стали практики коммеморационального характера - мероприятия по созданию новой политической символики, установлению праздничных и памятных дат, сооружению памятников, созданию исторических памятных мест, изменению тематических экспозиций музеев, по привлечению внимания к одним сюжетам истории и замалчиванию других. Специальным предметом исследований стали символические образы, медийные и визуальные формы реализации политики памяти на постсоветском пространстве, включая вопросы символической репрезентации исторической памяти в публичном городском пространстве [17; 18$]$.

В целом, уральские ученые основную перспективу теоретико-методологических исследований разнообразных политических дискурсов видят в актуализации задач по разработке на государственном уровне стратегических проектов, направленных на развитие отечественных ресурсов и технологий мягкой силы, мобильности, информационного обеспечения управления, расширения процесса медиатизации в конкретных областях общественной жизни. Особое внимание предполагается уделять вопросам секьюритизации политической дискурсологии, изучению политических дискурсов в контексте проблем укрепления информационной и интеллектуальной безопасности России.

1. Астафурова Т.Н., Акименко Н.А. Англосаксонский сказочный дискурс // Научный журнал «Дискурс-Пи». 2016. № 2 (23). С. 102-104.

2. Астафурова Т.Н., Захаров С.В. Дискурс англосаксонской институциональной глюттонии // Научный журнал «Дискурс-Пи». 2016. № 1 (22). С. 122 125 .

3. Астафурова Т.Н., Олянич А.В. Сакральный дискурс // Научный журнал «Дискурс-Пи». 2015. № 3-4 (20-21). С. 158-160.

4. Богомяков В.Г. Дискурс политики третьего тысячелетия. - Екатеринбург: Издательский дом «Дискурс-Пи», 2010. - 140 с.

5. Богомяков В.Г. Региональная идентичность «земли тюменской»: мифы и дискурс. - Екатеринбург: Издательский дом «Дискурс-Пи», 2007. $148 \mathrm{c.}$

6. Вести МАДИ // Научно-практический альманах «Дискурс-Пи». 2008. № 8. С. 137-140.

7. Вторая международная конференция «Soft Power: теория, ресурсы, дискурс» (Россия, Екатеринбург, 20 октября 2017 г.). Доклады // Научный журнал «Дискурс-Пи». 2017. № 3-4 (28-29). С. 90-188; 229-275.

8. Гаврилова М.В. Послание Федеральному Собранию. Программа политической партии. Парламентский дискурс. Президентский дискурс. Дискурсивный портрет В.В. Путина. Инаугурационная речь. Когнитивные исследования политического дискурса // Научный журнал «Дискурс-Пи». 2013. № 13. C. $111-117$.

9. Грибовод Е.Г. Медиадискурс. Интернет-дискурс. Социальнополитическое проектирование // Научный журнал «Дискурс-Пи».2013. № 13. C. $118-120$.

10. Грибовод Е.Г. Мобильность как атрибут медиатизации политики // Научный журнал «Дискурс-Пи». 2015. № 2 (19). С. 75-77. 
11. Грибовод Е.Г., Русакова О.Ф. Исследовательские направления и персонология Уральской школы политической дискурсологии (2001-2008) // Дискурсология: методология, теория, практика. Доклады Третьей международной научно-практической конференции, посвященной 40-летию студенческой революции 1969 г. и корифеям Франкфуртской школы. / Под общей ред. О.Ф. Русаковой. -2 октября - 19 декабря 2008 г. Том 1. - Екатеринбург: Издательский Дом «Дискурс-Пи», 2008. С. 76-80.

12. Дискурс травелога. Сборник статей. Авт. - сост.: О.Ф. Русакова, В.М. Русаков. Екатеринбург, ИМС - Издательский дом «Дискурс-Пи», Уральский финансово-юридический институт, 2009. - 190 с.

13. Дискурс философского пути. Материалы круглого стола VI Российского философского конгресса. Нижний Новгород, 27-30 июня 2012 г. / Под ред. О.Ф. Русаковой. - Екатеринбург: ИД «Дискурс-Пи», 2012. - 128 с.

14. Дискурсология: методология, теория, практика: доклады Третьей междунар. науч. - практ. конфер. посвященной 40-летию студенческой революции 1969 г. и корифеям Франкфуртской школы. / Под общей ред. О.Ф. Русаковой, В.Е. Хвощева, М.А. Малышева. 2 окт. - 19 дек. 2008 г. Россия-Мексика-Екатеринбург, Челябинск: Изд. Дом «Дискурс-Пи», Изд-во ЮУрГУ, 2009. T. 2. $-381 \mathrm{c}$.

15. Дискурсология: методология, теория, практика (Discursologia: metodologia, teoria, practica): доклады четвертой Междунар. науч.-практ. конфер.; ноябрь - декабрь 2009 года. Россия-Мексика / Под общей ред. М.А. Малышева, О.Ф. Русаковой, В.Е. Хвощева. - Челябинск: Изд. центр ЮУрГУ, 2010. $-552 \mathrm{c}$.

16. Дискурсология; методология, теория, практика: доклады пятой Международной научно-практической конференции, посвященной памяти Льва Николаевича Толстого и его идеям ненасильственного сопротивления. 19-20 ноября 2010 года. Россия-Мексика / под общей редакцией М.А. Малышева и В.Е. Хвощева. - Челябинск: Издательский центр ЮУрГУ; Изд-во НОЦ «КПОН», 2011. - $448 \mathrm{c}$.

17. Ильченко М.С. Риторика советского прошлого в современной российской политике // Россия в поисках идеологии: трансформация ценностных регуляторов современных обществ / под ред. В.С. Мартьянова, Л.Г. Фишмана. - М.: Политическая энциклопедия, 2016. (Глава 3.4). С. 215-238.

18. Ильченко М.С. Российский мегаполис в логике постфордизма: «Точка роста» или «Зона неопределенности»? //Устойчивое развитие России: вызовы, риски, стратегии. Материалы IXI Международной научно-практической конференции: к 25-летию Гуманитарного университета. 2016. Издательство: Автономная некоммерческая организация высшего образования «Гуманитарный университет». Екатеринбург. 2017. С. 149-153.

19. Исаков А.С. Дискурс мобильности в исламе: политологический анамнез // Научный журнал «Дискурс-Пи». 2015. № 2 (19). С. 57-63.

20. Исаков А.С. Маликитское измерение дискурса мобильности в исламе // Научный журнал «Дискурс-Пи». 2017. № 2 (27). С. 93-102.

21. Ишменев Е.В. Политический медиадискурс: теория и национальные модели. - Екатеринбург: ИД «Дискурс-Пи», 2012. - 128 с. 
22. Ковба Д.М. Фактор мобильности с точки зрения теории «мягкой силы» // Научный журнал «Дискурс-Пи». 2015. № 2 (19) С. 53-56.

23. Кожемякин Е.А. Дискурсная компетентность. Дискурсный подход к изучению культуры. Когерентность дискурса. Религиозный дискурс. Субъект дискурса. Юридический дискурс. // Научный журнал «Дискурс-Пи». 2013. № 13. С. 121-127.

24. Кожемякин Е.А., Кротов Е.А. Философский дискурс // Дискурс-Пи: научно-практический альманах. 2010. № 10. С. 347-348.

25. Кочнева Е.Д. Современные тренды студенческой мобильности // Научный журнал «Дискурс-Пи». 2013. № 13. С. 36-39.

26. Кочнева Е.Д. Политика памяти в России как систематическая работа с прошлым // Научный журнал «Дискурс-Пи». 2015. № 3-4 (20-21). С. 50-56.

27. Кротков Е.А., Кожемякин Е.А. Дискурс толерантности. Научный дискурс. Социально-исторический дискурс // Дискурс-Пи: научно-практический альманах. 2010. № 10. С. 137-141.

28. Макаров Д., Кузнецов А. Дискурсология: проблемы и вызовы сегодняшнего дня // Свободная мысль. 2007. № 6 (1577). С. 217-221.

29. Мартьянов В.С. Об условиях возникновения теории справедливости в российской политике // Полис. 2006. № 4. С. 61-73.

30. Многообразие политического дискурса Екатеринбург: ИФиП УрО РАН, УрГСХА, 2004. - 385 с.

31. Мобильность как измерение мягкой силы: Теория, практика, дискурс: материалы Всероссийской научно-практической молодежной конференции (Екатеринбург, 17 октября 2018). Научное электронное издание / Ред. О.Ф. Русакова, Д.М. Ковба - Екатеринбург: Издательский Дом «Дискурс-Пи», 2018. $-110 \mathrm{c}$.

32. Моисеенко Я.Ю. Мобильность как фактор политической социализации индивида // Научный журнал «Дискурс-Пи». 2013. № 13. С. 40-43.

33. Моисеенко Я.Ю. Мобильность как свойство массового конформистского сознания // Научный журнал «Дискурс-Пи». 2015. № 2 (19). С. 39-46.

34. Мягкая сила: очаровательная и соблазнительная политика // Наука Урала, декабрь 2014, № 22-23.

35. Новак М.В., Кожемякин Е.А. Движение как метафора в консьюмеристском дискурсе современной культуры // Научный журнал «Дискурс-Пи». 2013. № 13. С. 12-18.

36. Олянич А.В. Автомобильный дискурс. Вакхический дискурс. Гастрономический дискурс // Научный журнал «Дискурс-Пи». 2015. № 2 (19). C. $153-160$.

37. Олянич А.В., Захарова А.С. Ихтио- и аквадискурс // Научный журнал «Дискурс-Пи». 2015. № 3-4 (20-21). С. 150-155.

38. Постфордизм: концепции, институты, практики / под ред. М.С. Ильченко, В.С. Мартьянова. - М.: Политическая энциклопедия, 2015. - 279 с.

39. Романова К. Дискурсология: ответы и вызовы времени // Наука Урала. Январь 2009. № 2-3.

40. Романова К.С. Новые формы мобильности в травелоге // Научный журнал «Дискурс-Пи». 2013. № 13. С. 26-30. 
41. Романова К.С. Социальные лифты как средство социальной мобильности // Научный журнал «Дискурс-Пи». 2015. № 2 (19). С. 30-34.

42. Романова К.С. Анекдот как дискурс. Дискурс имиджа. Дискурс имени // Научный журнал «Дискурс-Пи». 2016. № 2 (23). С. 108-112.

43. Романова К.С. Дискурсы исторической памяти // Научный журнал «Дискурс-Пи». 2016. № 3 (24). С. 31-36.

44. Русаков В.М. Ноmo viator - через призму его травелогов на рубеже XX-XXI вв. // Научный журнал «Дискурс-Пи». 2013. № 13. С. 31-36.

45. Русаков В.М., Русакова О.Ф. Философия мобильности в современном мире // Научный журнал «Дискурс-Пи». 2015. № 2 (19). С. 10-18.

46. Русакова О.Ф. Основные разновидности современных теорий политического дискурса: опыт классификаций // ПОЛИТЭКС: Политическая экспертиза. Т. 2, № 3 СПб., 2006. - С. 191-212.

47. Русакова О.Ф. Современная политическая философия: предмет, концепты, дискурс. - Екатеринбург: ИД «Дискурс-Пи», 2012. - 400 с.

48. Русакова О.Ф. Метафорика и концептосфера дискурса мобильности // Научный журнал «Дискурс-Пи». 2013. № 13. С. 19-25.

49. Русакова О.Ф. Мобильность как значимая характеристика мягкой силы: концептуальные аспекты // Мобильность как измерение мягкой силы: теория, практика, дискурс: материалы Всероссийской научно-практической молодежной конференции (Екатеринбург, 17 октября 2018). Научное электронное издание / Ред. О.Ф. Русакова, Д.М. Ковба. - Екатеринбург: Издательский Дом «Дискурс-Пи», 2018. - 110 с. С. 69-72.

50. Русакова О.Ф., Грибовод Е.Г. Некоторые итоги первого этапа Международной конференции «Soft power»: теория, ресурсы, дискурс // Научный журнал «Дискурс-Пи». 2014. № 4. С. 191-193.

51. Русакова О.Ф., Грибовод Е.Г. Политический медиадискурс и медиатизация политики как концепты политической коммуникативистики // Науч. ежегодник Ин-та философии и права Урал. отд-ния Рос. акад. наук. - 2014. Т. 14, вып. 4. - С. 65-77.

52. Русакова О.Ф., Ковба Д.М., Моисеенко Я.Ю. «Мягкая сила»: новые исследования // Наука Урала. 24.11.2017. URL: www.uran.ru/node/5124.

53. Русакова О.Ф., Кочнева Е.Д. Оценки Октябрьской революции в официальном дискурсе политики памяти // Научный журнал «Дискурс-Пи». 2017, № 3-4 (28-29). C. 17-30.

54. Русакова О.Ф., Максимов Д.А. Политическая дискурсология: предметное поле, теоретические подходы и структурная модель политического дискурса // Полис. 2006. № 4. С. 26-43.

55. Русакова О.Ф., Русаков В.M. PR-дискурс: Теоретикометодологический анализ. - 2-е изд., испр. и доп. - Екатеринбург: УрО РАН, ИД «Дискурс-Пи», 2011. - 336 с.

56. Русакова О.Ф., Русаков В.М. Дискурсы и концепты «мягкого влияния» в современном гуманитарном знании // Вестник Новосибирского государственного университета. Серия: Философия. Т. 10, Вып. 3. 2012. С. 161-167.

57. Русакова О.Ф., Русаков В.М. Круглый стол «Философия, культура и дискурс мобильности» на VII Российском Философском Конгрессе // Науч- 
ный журнал «Дискурс-Пи». 2015. № 3-4 (20-21). С. 144-146.

58. Русакова О.Ф., Русаков В.М. Современный дискурс политики памяти // Российская политическая наука: идеи, концепции, методы: Научное издание / Под ред. Л.В. Сморгунова. - М.: Издательство «Аспект Пресс», 2015. C. $228-238$.

59. Русакова О.Ф., Русаков В.М. «Дискурс-Пи» 2001-2015 гг.: история современности через призму научного журнала // Научный журнал «ДискурсПи». 2015. № 3-4 (20-21). С. 10-16.

60. Русакова О.Ф., Русаков В.М. Итоги Второй мировой войны в свете европейского дискурса политики памяти // Философия войны и мира. К 70-летию Великой Победы: Материалы Всероссийской научнго-практической конференции «Философия войны и мира: к 70-летию Победы в Великой Отечественной войне». 28-29 апреля 2015 года. Москва, Институт философии РАН. - М.: Российское философское общество, ООО «СиДИПрессАрт», 2016. 496 с. C. $228-240$.

61. Русакова О.Ф., Русаков В.М. Великая Отечественная война и политика исторической памяти. Часть I // Научный журнал «Дискурс-Пи». 2016. № 1 (22). С. 10-17.

62. Русакова О.Ф., Русаков В.М. Великая Отечественная война и политика исторической памяти. Часть II // Научный журнал «Дискурс-Пи». 2016. № 2 (23). С. 8-17.

63. Русакова О.Ф., Русаков В.М. Парадигма мобильности в современном политическом медиадискурсе // Вопросы политологии. Выпуск 4 (24). 2016. C. 79-87.

64. Русакова О.Ф., Русаков В.М. «Мягкая сила» как инструмент политической коммуникации и гуманитарной дипломатии // Научный журнал «Дискурс-Пи». 2017. № 1 (26). С. 61-72.

65. Русакова О.Ф., Русаков В.М. Проблемы концептуального моделирования сущности большевизма: переход к парадигме мобильности (к 100-летию Великого Октября) // Научный журнал «Дискурс-Пи». 2017. № 2. С. 12-21.

66. Русакова О.Ф., Синельникова Л.Н. IV Международная конференция «Стилистика сегодня и завтра» и создание Ялтинского дискурсологического кружка // Научный журнал «Дискурс-Пи». 2016. № 1 (22). С. 144-147.

67. Русакова О.Ф., Фадеичева М.А., Грибовод Е.Г. Уральская школа политической дискурсологии: инновационные направления исследований // Доклады Второй Междунар. Науч. - практ. конфер., посвященной памяти Жана Бодрийяра. / Под общей ред. О.Ф. Русаковой. - 21 ноября - 14 декабря 2007 г. Том. 2. Екатеринбург: Издательский. Дом «Дискурс Пи», 2007. С. 41-43.

68. Синельникова Л.Н. Дискурс троллинга. Дискурс фразеологических новообразований // Научный журнал «Дискурс-Пи».2016. № 3-4 (24-25). C. 271-285.

69. Современные теории дискурса: мультидисциплинарный анализ. (Cерия «Дискурсология». Выпуск 1). Екатеринбург: Издательский Дом «ДискурсПи», 2006. - 210 с.

70. Трахтенберг А.Д. Дискурсивный анализ массовой коммуникации и парадоксы левого сознания // Полис. 2006. № 4. С. 44-52. 
71. Фадеичева М.А. Дискурс научной конференции: «Дискурсология: Методология. Теория. Практика» // Научный журнал «Дискурс-Пи». 2013. № 1-2 (11-12). С. 294-297.

72. Фадеичева М.А. Идеология и дискурсивные практики «нашизма» в современной России // Полис. 2006. № 4. С. 53-60.

73. Фан И.Б. Гражданственность в отечественном политическом дискурсе, или к проблеме о том, есть ли демократический потенциал у «русской идеи»? // Политэкс: Политическая экспертиза. 2006. Т. 2, № 2. С. 145-156.

74. Фан И.Б. Дискурс мобильности и проблематизация национального гражданства // Научный журнал «Дискурс-Пи». 2015. № 2 (19). С. 24-29.

75. Фан И.Б. Концепт гражданина в западноевропейской истории и культуре. Концепт гражданина в российской истории и культуре // Научный журнал «Дискурс-Пи». 2017. № 1 (26). С. 154-159.

76. Фан И.Б. Концепт гражданина в российской истории и культуре // Научный журнал «Дискурс-Пи». 2017. № 1 (26). С. 160-163.

77. Фан И.Б. Либеральный дискурс гражданственности // Научный журнал «Дискурс-Пи». 2017. № 2. С. 170-173.

78. Фурсов К.К. Проявление дискурса вражды в жанре автобиографии в рамках процесса вертикальной политической мобильности // Научный журнал «Дискурс-Пи». 2015. № 2 (19). С. 47-52.

79. Хмелинин А.А., Русакова О.Ф. Идеологическая мобильность современного неолиберализма: методологический анализ // Научный журнал «Дискурс-Пи». 2013. № 13. С. 88-91.

80. Soft power: теория, ресурсы, дискурс / под ред. О.Ф. Русаковой. Екатеринбург: Издательский Дом «Дискурс-Пи», 2015. - 376 с.

\section{References}

1. Astafurova T.N., Akimenko N.A. Anglosaksonskij skazochnyj diskurs // Nauchnyj zhurnal «Diskurs-Pi». 2016. № 2 (23). S. 102-104.

2. Astafurova T.N., Zaxarov S.V. Diskurs anglosaksonskoj institucional'noj glyuttonii // Nauchnyj zhurnal «Diskurs-Pi». 2016. № 1 (22). S. 122-125.

3. Astafurova T.N., Olyanich A.V. Sakral'nyj diskurs // Nauchnyj zhurnal «Diskurs-Pi». 2015. № 3-4 (20-21). S. 158-160.

4. Bogomyakov V.G. Diskurs politiki tret'ego tysyacheletiya. - Ekaterinburg: Izdatel'skij dom «Diskurs-Pi», 2010. - $140 \mathrm{~s}$.

5. Bogomyakov V.G. Regional'naya identichnost' «zemli tyumenskoj»: mify i diskurs. - Ekaterinburg: Izdatel'skij dom «Diskurs-Pi», 2007. - $148 \mathrm{~s}$.

6. Vesti MADI // Nauchno-prakticheskij al'manax «Diskurs-Pi». 2008. № 8. S. $137-140$.

7. Vtoraya mezhdunarodnaya konferenciya «Soft Power: teoriya, resursy, diskurs» (Rossiya, Ekaterinburg, 20 oktyabrya 2017 g.). Doklady // Nauchnyj zhurnal «Diskurs-Pi». 2017. № 3-4 (28-29). S. 90-188; 229-275.

8. Gavrilova M.V. Poslanie Federal'nomu Sobraniyu. Programma politicheskoj partii. Parlamentskij diskurs. Prezidentskij diskurs. Diskursivnyj portret V.V. Putina. Inauguracionnaya rech'. Kognitivnye issledovaniya politicheskogo 
diskursa // Nauchnyj zhurnal «Diskurs-Pi». 2013. № 13. S. 111-117.

9. Gribovod E.G. Mediadiskurs. Internet-diskurs. Social'no-politicheskoe proektirovanie // Nauchnyj zhurnal «Diskurs-Pi».2013. № 13. S. 118-120.

10. Gribovod E.G. Mobil'nost' kak atribut mediatizacii politiki // Nauchnyj zhurnal «Diskurs-Pi». 2015. № 2 (19). S. 75-77.

11. Gribovod E.G., Rusakova O.F. Issledovatel'skie napravleniya i personologiya Ural'skoj shkoly politicheskoj diskursologii (2001-2008) // Diskursologiya: metodologiya, teoriya, praktika. Doklady Tret'ej mezhdunarodnoj nauchno-prakticheskoj konferencii, posvyashhennoj 40-letiyu studencheskoj revolyucii 1969 g. i korifeyam Frankfurtskoj shkoly. / Pod obshhej red. O.F. Rusakovoj. - 2 oktyabrya - 19 dekabrya 2008 g. Tom 1. - Ekaterinburg: Izdatel'skij Dom «Diskurs-Pi», 2008. S. 76-80.

12. Diskurs traveloga. Sbornik statej.Avt.-sost.: O.F. Rusakova, V.M. Rusakov. Ekaterinburg, IMS - Izdatel'skij dom «Diskurs-Pi», Ural'skij finansovo-yuridicheskij institut, 2009. - $190 \mathrm{~s}$.

13. Diskurs filosofskogo puti. Materialy kruglogo stola VI Rossijskogo filosofskogo kongressa. Nizhnij Novgorod, 27-30 iyunya 2012 g. / Pod red. O.F. Rusakovoj. - Ekaterinburg: ID «Diskurs-Pi», 2012. - 128 s.

14. Diskursologiya: metodologiya, teoriya, praktika: doklady Tret'ej mezhdunar. nauch. - prakt. konfer. posvyashhennoj 40-letiyu studencheskoj revolyucii 1969 g. i korifeyam Frankfurtskoj shkoly. / Pod obshhej red. O.F. Rusakovoj, V.E. Xvoshheva, M.A. Malysheva. 2 okt. - 19 dek. 2008 g. RossiyaMeksika-Ekaterinburg, Chelyabinsk: Izd. Dom «Diskurs-Pi», Izd-vo YuUrGU, 2009. T. 2. $-381 \mathrm{~s}$.

15. Diskursologiya: metodologiya, teoriya, praktika (Discursologia: metodologia, teoria, practica): doklady chetvertoj Mezhdunar. nauch.-prakt. konfer.; noyabr' - dekabr' 2009 goda. Rossiya-Meksika / Pod obshhej red. M.A. Malysheva, O.F. Rusakovoj, V.E. Xvoshheva. - Chelyabinsk: Izd. centr YuUrGU, 2010. - 552 s.

16. Diskursologiya; metodologiya, teoriya, praktika: doklady pyatoj Mezhdunarodnoj nauchno-prakticheskoj konferencii, posvyashhennoj pamyati L'va Nikolaevicha Tolstogo i ego ideyam nenasil'stvennogo soprotivleniya. 1920 noyabrya 2010 goda. Rossiya-Meksika / pod obshhej redakciej M.A. Malysheva i V.E. Xvoshheva. - Chelyabinsk: Izdatel'skij centr YuUrGU; Izd-vo NOC «KPON», 2011. $-448 \mathrm{~s}$.

17. Il'chenko M.S. Ritorika sovetskogo proshlogo v sovremennoj rossijskoj politike // Rossiya v poiskax ideologii: transformaciya cennostnyx regulyatorov sovremennyx obshhestv / pod red. V.S. Mart'yanova, L.G. Fishmana. - M.: Politicheskaya e'nciklopediya, 2016. (Glava 3.4). S. 215-238.

18. Il'chenko M.S. Rossijskij megapolis v logike postfordizma: «Tochka rosta» ili «Zona neopredelennosti»? //Ustojchivoe razvitie Rossii: vyzovy, riski, strategii. Materialy IXI Mezhdunarodnoj nauchno-prakticheskoj konferencii: k 25-letiyu Gumanitarnogo universiteta. 2016. Izdatel'stvo: Avtonomnaya nekommercheskaya organizaciya vysshego obrazovaniya «Gumanitarnyj universitet». Ekaterinburg. 2017. S. 149-153.

19. Isakov A.S. Diskurs mobil'nosti v islame: politologicheskij anamnez // Nauchnyj zhurnal «Diskurs-Pi». 2015. № 2 (19). S. 57-63. 
20. Isakov A.S. Malikitskoe izmerenie diskursa mobil'nosti v islame // Nauchnyj zhurnal «Diskurs-Pi». 2017. № 2 (27). S. 93-102.

21. Ishmenev E.V. Politicheskij mediadiskurs: teoriya i nacional'nye modeli. Ekaterinburg: ID «Diskurs-Pi», 2012. - 128 s.

22. Kovba D.M. Faktor mobil'nosti s tochki zreniya teorii «myagkoj sily» // Nauchnyj zhurnal «Diskurs-Pi». 2015. № 2 (19) S. 53-56.

23. Kozhemyakin E.A. Diskursnaya kompetentnost'. Diskursnyj podxod k izucheniyu kul'tury. Kogerentnost' diskursa. Religioznyj diskurs. Sub"ekt diskursa. Yuridicheskij diskurs. // Nauchnyj zhurnal «Diskurs-Pi». 2013. № 13. S. 121-127.

24. Kozhemyakin E.A., Krotov E.A. Filosofskij diskurs // Diskurs-Pi: nauchno-prakticheskij al'manax. 2010. № 10. S. 347-348.

25. Kochneva E. D. Sovremennye trendy studencheskoj mobil'nosti //Nauchnyj zhurnal «Diskurs-Pi». 2013. № 13. S. 36-39.

26. Kochneva E.D. Politika pamyati v Rossii kak sistematicheskaya rabota s proshlym // Nauchnyj zhurnal «Diskurs-Pi». 2015. № 3-4 (20-21). S. 50-56.

27. Krotkov E.A., Kozhemyakin E.A. Diskurs tolerantnosti. Nauchnyj diskurs. Social'no-istoricheskij diskurs // Diskurs-Pi: nauchno-prakticheskij al'manax. 2010. № 10. S. 137-141.

28. Makarov D., Kuznecov A. Diskursologiya: problemy i vyzovy segodnyashnego dnya // Svobodnaya mysl'. 2007. № 6 (1577). S. 217-221.

29. Mart'yanov V.S. Ob usloviyax vozniknoveniya teorii spravedlivosti v rossijskoj politike // Polis. 2006. № 4. S. 61-73.

30. Mnogoobrazie politicheskogo diskursa Ekaterinburg: IFiP UrO RAN, UrGSXA, 2004. $-385 \mathrm{~s}$.

31. Mobil'nost'kak izmerenie myagkoj sily: Teoriya, praktika, diskurs: materialy Vserossijskoj nauchno-prakticheskoj molodezhnoj konferencii (Ekaterinburg, 17 oktyabrya 2018). Nauchnoe e'lektronnoe izdanie / Red. O.F. Rusakova, D.M. Kovba - Ekaterinburg: Izdatel'skij Dom «Diskurs-Pi», 2018. - 110 s.

32. Moiseenko Ya.Yu. Mobil'nost' kak faktor politicheskoj socializacii individa // Nauchnyj zhurnal «Diskurs-Pi». 2013. № 13. S. 40-43.

33. Moiseenko Ya. Yu. Mobil'nost' kak svojstvo massovogo konformistskogo soznaniya // Nauchnyj zhurnal «Diskurs-Pi». 2015. № 2 (19). S. 39-46.

34. Myagkaya sila: ocharovatel'naya i soblaznitel'naya politika // Nauka Urala, dekabr' 2014, № 22-23.

35. Novak M.V., Kozhemyakin E.A. Dvizhenie kak metafora v kons'yumeristskom diskurse sovremennoj kul'tury // Nauchnyj zhurnal «DiskursPi». 2013. № 13. S. 12-18.

36. Olyanich A.V. Avtomobil'nyj diskurs. Vakxicheskij diskurs. Gastronomicheskij diskurs // Nauchnyj zhurnal «Diskurs-Pi». 2015. № 2 (19). S. $153-160$.

37. Olyanich A.V., Zaxarova A.S. Ixtio- i akvadiskurs // Nauchnyj zhurnal «Diskurs-Pi». 2015. № 3-4 (20-21). S. 150-155.

38. Postfordizm: koncepcii, instituty, praktiki / pod red. M.S. Il'chenko, V.S. Mart'yanova. - M.: Politicheskaya e'nciklopediya, 2015. - 279 s.

39. Romanova K. Diskursologiya: otvety i vyzovy vremeni // Nauka Urala. Yanvar' 2009. № 2-3. 
40. Romanova K. S. Novye formy mobil'nosti $v$ traveloge // Nauchnyj zhurnal «Diskurs-Pi». 2013. № 13. S. 26-30.

41. Romanova K.S. Social'nye lifty kak sredstvo social'noj mobil'nosti // Nauchnyj zhurnal «Diskurs-Pi». 2015. № 2 (19). S. 30-34.

42. Romanova K. S. Anekdot kak diskurs. Diskurs imidzha. Diskurs imeni // Nauchnyj zhurnal «Diskurs-Pi». 2016. № 2 (23). S. 108-112.

43. Romanova K.S. Diskursy istoricheskoj pamyati // Nauchnyj zhurnal «Diskurs-Pi». 2016. № 3 (24). S. 31-36.

44. Rusakov V.M. Homo viator - cherez prizmu ego travelogov na rubezhe XX-XXI vv. // Nauchnyj zhurnal «Diskurs-Pi». 2013. № 13. S. 31-36.

45. Rusakov V.M., Rusakova O.F. Filosofiya mobil'nosti v sovremennom mire // Nauchnyj zhurnal «Diskurs-Pi». 2015. № 2 (19). S. 10-18.

46. Rusakova O.F. Osnovnye raznovidnosti sovremennyx teorij politicheskogo diskursa: opyt klassifikacij // POLITE'KS: Politicheskaya e'kspertiza. T. 2, № 3 SPb., 2006. - S. 191-212.

47. Rusakova O.F. Sovremennaya politicheskaya filosofiya: predmet, koncepty, diskurs. - Ekaterinburg: ID «Diskurs-Pi», 2012. - 400 s.

48. Rusakova O.F. Metaforika i konceptosfera diskursa mobil'nosti // Nauchnyj zhurnal «Diskurs-Pi». 2013. № 13. S. 19-25.

49. Rusakova O.F. Mobil'nost' kak znachimaya xarakteristika myagkoj sily: konceptual'nye aspekty // Mobil'nost' kak izmerenie myagkoj sily: teoriya, praktika, diskurs: materialy Vserossijskoj nauchno-prakticheskoj molodezhnoj konferencii (Ekaterinburg, 17 oktyabrya 2018). Nauchnoe e'lektronnoe izdanie / Red. O.F. Rusakova, D.M. Kovba. - Ekaterinburg: Izdatel'skij Dom «Diskurs-Pi», 2018. 110 s. S. $69-72$.

50. Rusakova O.F., Gribovod E.G. Nekotorye itogi pervogo e'tapa Mezhdunarodnoj konferencii «Soft power»: teoriya, resursy, diskurs // Nauchnyj zhurnal «Diskurs-Pi». 2014. № 4. S. 191-193.

51. Rusakova O.F., Gribovod E.G. Politicheskij mediadiskurs i mediatizaciya politiki kak koncepty politicheskoj kommunikativistiki // Nauch. ezhegodnik In-ta filosofii i prava Ural. otd-niya Ros. akad. nauk. - 2014. - T. 14, vyp. 4. - S. 65-77.

52. Rusakova O.F., Kovba D.M., Moiseenko Ya.Yu. «Myagkaya sila»: novye issledovaniya // Nauka Urala. 24.11.2017. URL: www.uran.ru/node/5124.

53. Rusakova O.F., Kochneva E.D. Ocenki Oktyabr'skoj revolyucii v oficial'nom diskurse politiki pamyati // Nauchnyj zhurnal «Diskurs-Pi». 2017, № 3-4 (28-29). S. 17-30.

54. Rusakova O.F., Maksimov D. A. Politicheskaya diskursologiya:predmetnoe pole, teoreticheskie podxody i strukturnaya model' politicheskogo diskursa // Polis. 2006. № 4. S. 26-43.

55. Rusakova O.F., Rusakov V.M. PR-diskurs: Teoretiko-metodologicheskij analiz. - 2-e izd., ispr. i dop. - Ekaterinburg: UrO RAN, ID «Diskurs-Pi», 2011. - 336 s.

56. Rusakova O.F., Rusakov V.M. Diskursy i koncepty «myagkogo vliyaniya» v sovremennom gumanitarnom znanii // Vestnik Novosibirskogo gosudarstvennogo universiteta. Seriya: Filosofiya. T. 10, Vyp. 3. 2012. C. 161-167.

57. Rusakova O.F., Rusakov V.M. Kruglyj stol «Filosofiya, kul'tura i diskurs 
mobil'nosti» na VII Rossijskom Filosofskom Kongresse // Nauchnyj zhurnal «Diskurs-Pi». 2015. № 3-4 (20-21). S. 144-146.

58. Rusakova O.F., Rusakov V.M. Sovremennyj diskurs politiki pamyati // Rossijskaya politicheskaya nauka: idei, koncepcii, metody: Nauchnoe izdanie / Pod red. L. V. Smorgunova. - M.: Izdatel'stvo «Aspekt Press», 2015. S. 228-238.

59. Rusakova O.F., Rusakov V.M. «Diskurs-Pi» 2001-2015 gg.: istoriya sovremennosti cherez prizmu nauchnogo zhurnala // Nauchnyj zhurnal «Diskurs-Pi». 2015. № 3-4 (20-21). S. 10-16.

60. Rusakova O.F., Rusakov V.M. Itogi Vtoroj mirovoj vojny v svete evropejskogo diskursa politiki pamyati // Filosofiya vojny i mira. K 70-letiyu Velikoj Pobedy: Materialy Vserossijskoj nauchngo-prakticheskoj konferencii «Filosofiya vojny i mira: k 70-letiyu Pobedy v Velikoj Otechestvennoj vojne». 28-29 aprelya 2015 goda. Moskva, Institut filosofii RAN. - M.: Rossijskoe filosofskoe obshhestvo, OOO «SiDIPressArt», 2016. - 496 s. S. 228-240.

61. Rusakova O.F., Rusakov V.M. Velikaya Otechestvennaya vojna i politika istoricheskoj pamyati. Chast' I // Nauchnyj zhurnal «Diskurs-Pi». 2016. № 1 (22). S. $10-17$.

62. Rusakova O.F., Rusakov V.M. Velikaya Otechestvennaya vojna i politika istoricheskoj pamyati. Chast' II // Nauchnyj zhurnal «Diskurs-Pi». 2016. № 2 (23). S. $8-17$.

63. Rusakova O.F., Rusakov V.M. Paradigma mobil'nosti v sovremennom politicheskom mediadiskurse // Voprosy politologii. Vypusk 4 (24). 2016. S. 79-87.

64. Rusakova O.F., Rusakov V.M. «Myagkaya sila» kak instrument politicheskoj kommunikacii i gumanitarnoj diplomatii // Nauchnyj zhurnal «DiskursPi». 2017. № 1 (26). S. 61-72.

65. Rusakova O.F., Rusakov V.M. Problemy konceptual'nogo modelirovaniya sushhnosti bol'shevizma: perexod k paradigme mobil'nosti (k 100-letiyu Velikogo Oktyabrya) // Nauchnyj zhurnal «Diskurs-Pi». 2017. № 2. S. 12-21.

66. Rusakova O.F., Sinel'nikova L.N. IV Mezhdunarodnaya konferenciya «Stilistika segodnya i zavtra» i sozdanie Yaltinskogo diskursologicheskogo kruzhka // Nauchnyj zhurnal «Diskurs-Pi». 2016. № 1 (22). S. 144-147.

67. Rusakova O.F., Fadeicheva M.A., Gribovod E.G. Ural'skaya shkola politicheskoj diskursologii: innovacionnye napravleniya issledovanij // Doklady Vtoroj Mezhdunar. Nauch. - prakt. konfer., posvyashhennoj pamyati Zhana Bodrijyara. / Pod obshhej red. O.F. Rusakovoj. - 21 noyabrya - 14 dekabrya 2007 g. Tom. 2. Ekaterinburg: Izdatel'skij. Dom «Diskurs Pi», 2007. S. 41-43.

68. Sinel'nikova L.N. Diskurs trollinga. Diskurs frazeologicheskix novoobrazovanij // Nauchnyj zhurnal «Diskurs-Pi».2016. № 3-4 (24-25). S. 271285.

69. Sovremennye teorii diskursa: mul'tidisciplinarnyj analiz. (Seriya «Diskursologiya». Vypusk 1). Ekaterinburg: Izdatel'skij Dom «Diskurs-Pi», 2006. $210 \mathrm{~s}$.

70. Traxtenberg A. D. Diskursivnyj analiz massovoj kommunikacii i paradoksy levogo soznaniya // Polis. 2006. № 4. S. 44-52.

71. Fadeicheva M.A. Diskurs nauchnoj konferencii: «Diskursologiya: Metodologiya. Teoriya. Praktika» // Nauchnyj zhurnal «Diskurs-Pi». 2013. 
№ 1-2 (11-12). S. 294-297.

72. Fadeicheva M.A. Ideologiya i diskursivnye praktiki «nashizma» v sovremennoj Rossii // Polis. 2006. № 4. S. 53-60.

73. Fan I.B. Grazhdanstvennost' v otechestvennom politicheskom diskurse, ili k probleme o tom, est' li demokraticheskij potencial u «russkoj idei»? // Polite'ks: Politicheskaya e'kspertiza. 2006. T. 2, № 2. S. 145-156.

74. Fan I.B. Diskurs mobil'nosti i problematizaciya nacional'nogo grazhdanstva // Nauchnyj zhurnal «Diskurs-Pi». 2015. № 2 (19). S. 24-29.

75. Fan I.B. Koncept grazhdanina v zapadnoevropejskoj istorii i kul'ture. Koncept grazhdanina v rossijskoj istorii i kul'ture // Nauchnyj zhurnal «Diskurs-Pi». 2017. № 1 (26). S. 154-159.

76. Fan I.B. Koncept grazhdanina v rossijskoj istorii i kul'ture // Nauchnyj zhurnal «Diskurs-Pi». 2017. № 1 (26). S. 160-163.

77. Fan I.B. Liberal'nyj diskurs grazhdanstvennosti // Nauchnyj zhurnal «Diskurs-Pi». 2017. № 2. S. 170-173.

78. Fursov K.K. Proyavlenie diskursa vrazhdy v zhanre avtobiografii v ramkax processa vertikal'noj politicheskoj mobil'nosti // Nauchnyj zhurnal «Diskurs-Pi». 2015. № 2 (19). S. 47-52.

79. XmelininA.A., Rusakova O.F. Ideologicheskaya mobil'nost' sovremennogo neoliberalizma: metodologicheskij analiz // Nauchnyj zhurnal «Diskurs-Pi». 2013. № 13. S. 88-91.

80. Soft power: teoriya, resursy, diskurs / pod red. O.F. Rusakovoj. Ekaterinburg: Izdatel'skij Dom «Diskurs-Pi», 2015. - 376 s. 
UDC $316+327+32.019$

DOl 10.17506/dipi.2018.31.2.1029

\section{URAL SCHOOL \\ OF POLITICAL DISCOURSE STUDIES: \\ NEWEST RESEARCH AREAS \\ AND ACADEMIC PRACTICES}

\section{Rusakova Olga Fredovna,}

Institute of Philosophy and Law

of the Ural Branch of the Russian Academy of Sciences,

Doctor of Political Sciences, Professor,

Ekaterinburg, Russia,

E-mail: rusakova_mail@mail.ru

\section{Annotation}

The article discusses the newest directions of development by Ural scientists, primarily in the face of researchers and graduate students of the Institute of Philosophy and Law of the Ural Branch of the Russian Academy of Sciences, the theoretical and methodological basis of political discourse science as a new branch of modern political research. The content of the main thematic blocks of political discourse, which received theoretical development in collective works and monographs of Ural scholars published in recent years, is revealed. The most important results of the implementation of specific research projects in the field of political discourse are considered, the experience of organizing a scientific exchange in the format of conferences is analyzed.

Key concepts:

political discourse, political discourse, media discourse, soft power discourse, mobility discourse, memory policy discourse, Modernity discourse, post -formal discourse, postcapitalism discourse, neo-Marxist discourse, citizenship discourse, transhumanism discourse, discourse of humanitarian interventions, academic discourse. 